\title{
Using Audio/Visual Media, Specifically VoiceThread, as a Vehicle for Teaching and Learning: Do Teacher Candidates Capitalize on This Opportunity?
}

\author{
Carol Klages, Ph.D. and Jane Fry, Ed.D. \\ School of Education, Health Professions, and Human Development, University of Houston-Victoria \\ Email: klagesc@uhv.edu
}

\begin{abstract}
Students today are called "digital natives" because they are born into a virtual world, with accessibility to cell phones, computers, iPods, and YouTube (Prensky 2001). Digital natives see technology as the framework for learning in and out of the classroom. However, their experience and enthusiasm for technology is not embraced by many teachers. This investigation describes teacher candidate perceptions of a secondary instructional strategy using the Voice Thread tool as a vehicle for teaching and learning.
\end{abstract}

Keywords: Virtual, technology, teacher, perceptions.

\section{Conceptual Framework}

\section{$1.1 \quad$ Introduction}

As soon as this article has been read, technology will have changed. While, most of today's public school students are keeping up with technology changes, many of the teachers and teacher candidates are not. Technology as a learning tool provides students with authentic knowledge and authentic learning opportunities. These authentic learning opportunities are how the digital natives (Prensky 2001) accept learning with technology. The teachers and teacher candidates who work with students, or digital natives, are not always as savvy when it comes to technology. To address the disconnection between digital natives, the students, and the teachers, a technology framework of pedagogical knowledge is necessary to provide educators with the potential to transform their lack of technical expertise or willingness to include such teaching and learning options (Mishra \& Koehler, 2006).

The current generation of public school students is active and skilled in utilizing the Internet as a tool for entertainment and learning. For these tech-savvy students, the Internet is an important tool for literacy skills such as reading, writing, and communicating, not that they necessarily realize it (Coiro and Dobler 2007; Leu, Kinzer Coiro and Cammack 2004; Leu et. al. 2007). As educators remain working in classrooms and teacher candidates prepare to enter the classrooms, they must encounter new literacies transformed by ICTs (Internet Communication Technologies) like word processors, instant messaging and electronic books. New literacies can be explained as social practices (Street 2003) or new Discourses (Gee 2003) that emerge with new technologies. In an effort to prepare and coach future educators on why technology components should play an active part of learning in the new literacies, these teacher candidates call for exposure to those new literacies. Through the use of new technologies such as Voice Thread, an atmosphere is created in which students feel they are important people in the classroom learning community who learn with and from teachers and technology. The Voice Thread tool is described later in the review literature.

\subsection{Who Are the Digital Natives?}

For teacher candidates to understand the significance of technology in the classroom, they must first understand the digital natives; their students. Research literature has generated numerous discussions about the technical knowledge of the youth of today. They have been labeled the Net Generation (Oblinger \& Oblinger, 2005); digital natives ( Prensky, 2001); Generation Y (Perillo, 2007), and 
Millenials (Howe \& Strauss, 2000) to name a few. Regardless of the label used, the understanding is that students are exposed to a variety of digital technologies that did not exist last year, last month or even last week (Brown \& Czerniewicz, 2010). For this research investigation, the term digital natives (Prensky, 2001) was employed as it refers to young people who specifically grew up with digital technology and not only are adept at using it on a regular basis; they seek its incorporation into classroom learning. According to McKenzie (2007), it is realistic to assume that the youth today, born after 1980 in developed countries, have had greater experience with digital technology than any other previous generations. As such, this experience may distance them from their teachers and significantly affect the learning opportunities provided in a classroom (Bennett, Maton, \& Kervin, 2008). Digital natives are described as learners who are active and experienced with the skills to multitask while accessing information on the Internet along with interacting with fellow learners (Oblinger \& Oblinger, 2005). With this description of today's students, one must determine if the current educator preparation programs and educational opportunities for learning meet the needs of such learners.

\subsection{Technological Pedagogical Knowledge: What Audio/Visual Skills do Teacher Candidates Posses and Utilize?}

The possibilities of new audio/visual media afford the ability to situate learning to enhance the creation of $21^{\text {st }}$ century skills. In other words, new technologies provide a bridge for non-digital natives to meet the needs of their students; the digital natives. Teacher candidates are presented with obstacles and questions of integrating technology into learning opportunities. In the 1980s, Shulman (1986) introduced Pedagogical Content Knowledge or PCK to the world of education. PCK included the content knowledge one needed to teach along with the skills of how to teach that content knowledge. As technology progressed and entered the world of students, the idea of PCK evolved into TPACK or Technological Pedagogical Content Knowledge. This framework, according to Mishra \& Koehler (2006), suggests that "Teachers need to know not just the subject matter they teach, but also the manner in which the subject matter can be changed by the application of technology (p. 1028)." TPACK is described as the ability of knowing and using a variety of technologies and understanding how they can be used to promote teaching and learning in a specific content area. Understanding of TPACK provides teacher candidates with a means to avoid teaching the way they were taught (Russell, Bebell, O'Dwyer \& O'Connor, 2003) which is primarily print from the $20^{\text {th }}$ century. Of course, print-based teaching and learning can be successful, but only for those with the print modality (Davis, 2002). In other words, many digital natives have moved on from this type of modality to one of more technology-based learning. Their teachers must move on as well or least start to move in that direction.

\subsection{Why Learn with Technology?}

For digital natives, technology provides great promise for learning. As such, it is necessary that the future teachers of these digital natives see the promise as well. In a recent survey of 108 teacher candidates, investigators noted that $72 \%$ had a positive view of utilizing technology into their future classroom. Unfortunately, only $16 \%$ actually possessed a plan of how to actually utilize that technology so that their students could collaborate and create (Redman and Trapani, 2012). Along with digital natives, business leaders state that it is important that schools and teachers provide learning opportunities for students to develop $21^{\text {st }}$ century skills (Partnership for $21^{\text {st }}$ Century Skills, 2010). Other significant organizations related to teaching and learning also promoted the need to learn with technology.

The federal government has made the role of technology in teaching and learning important when it mandated the National Technology Plan (U.S. Department of Education, 2004, 2010). The National Council for Accreditation of Teacher Education (NCATE) stated the importance of teaching and learning with technology in their professional standards NCATE, 2008), and, national education technology standards for teachers (NETS-T) were created by the International Society for Technology in Education (ISTE, 2002) and later adopted by NCATE. In addition, educator preparation programs have focused on preparing teacher candidates to include audio/visual media into their lesson plans (American Association of Colleges of Teacher Education [AACTE], 2002). If these important groups in the educational world are supporting the inclusion of technology into teaching and learning, then teacher 
candidates need to embrace the challenge. One such technology that can provide the learning opportunities for collaboration, creativity, and community is Voice Thread (http://voicethread.com).

Voice Thread is a computer tool that is purposeful for encouraging student engagement and motivation while promoting learning. It is an interactive, audio/visual tool that allows teacher candidates to have conversations around visuals, documents, and videos. This audio/visual tool is accessible for all as there is a free version, thus cost-effective. It is applicable in all content areas as well as most grade levels. This technology can be useful in a general education classroom as well as a resource classroom and inclusive settings. Voice Thread (VT) promotes collaboration in a large group or a small group, thus versatile (Brunvand \& Byrd, 2011). According to Johnson, Levine, Smith \& Smythe (2009), Voice Thread is a technical tool to utilize because of its opportunities for collaboration and communication. An easy method to learn about VT is on the website (http://voicethread.com/\#q.b409.i848804) which was created by its developers. A tool such as VT allows teacher candidates to employ learning beyond the print-based classroom.

\section{$2 \quad$ Research Design}

\subsection{Methodological Approach and Research Questions}

This investigation relied on an exploratory case study approach (Yin 2003) to examine the perceptions teacher candidates used for instructional strategies that employ audio/visual media, specifically Voice Thread. Among possible audio/visual media already in existence that could have been selected for analysis, it best served this investigation for the teacher candidates to create their own audio/visual media, Voice Thread, related to a secondary methods course.

The use of a student-created Voice Thread provided for consistency and frequency of participation. The Voice Thread was public for other participants to read, post, and/or engage with the teacher candidates and/or post information. Each teacher candidate was randomly placed in a group and provided with an instructional strategy as a topic. The instructor requirements were provided to the group. The following is a list of those requirements:

- $\quad$ Describe the instructional strategy

- $\quad$ Explain how the instructional strategy addressed the idea of a teacher-centered classroom or a student-centered classroom

- $\quad$ Demonstrate the instructional process

- $\quad$ Provide clear, specific steps for creating a lesson using this instructional strategy

- $\quad$ Each group member must provide some audio

- $\quad$ Each group member "must say something" to each of the other groups

- How student work can be evaluated when using the given instructional strategy

- $\quad$ Discuss how Voice Thread can be used in a secondary classroom

Specific step-by-step textual instructions of how to use Voice Thread were provided. These instructions were in addition to the audio/visual instructions from the Voice Thread website which was also provided to the students.

As the teacher candidates were still in the educator preparation program, it was not possible to directly record influences to their teaching practices that resulted from the Voice Thread experience, as such the following set of research questions (RQ) and subquestions were created to inform the case study:

RQ 1.How did teacher candidates incorporate secondary teaching methods into an audio/visual tool such as Voice Thread?

More specifically:

RQ 1.1. What did teacher candidates record in Voice Thread?

RQ 1.2. What comments did teacher candidates share on classmates' Voice Thread media?

RQ2. How did the use of Voice Thread influence the perceptions of teacher candidates who engaged in the audio/visual experience? 


\subsection{Participants and Context of the Investigation}

For this initial research investigation, seventeen senior- level teacher candidates enrolled in an educator preparation program at a public university in the south were utilized. These students can be classified as non-traditional students as they are older than the stereotypical junior or senior level college student. The course is a required general secondary methodology course for teacher candidates seeking secondary initial teacher certification in several content areas: mathematics, history, English, and Computer Science. The methods course is a required course taken the semester prior to student teaching. The course was delivered in an online format in a traditional 16 week spring semester. All teacher candidates in this class had at least two online teacher educator courses prior to this one. Participation in the Voice Thread was required, but, no specific guidelines for the number of visuals (video, slides, documents, etc.) were given. However, there was a minimum of two audio postings for viewing each group's Voice Thread. Within the context of the course, the teacher candidates did have to participate in the creation of the Voice Thread. This participation was left open in terms of frequency after the initial posting. In essence, the Voice Thread was a required portion of the class, as it was the only place in which students could provide, describe, share, and comment on various general secondary instructional strategies within confounds of the course.

\section{$2.3 \quad$ Data Sources}

In order to address the research questions previously articulated, the following data sources were used: All initial Voice Thread (VT) postings (audio, visual, textual) from 16 of the 17 students in an online secondary methodology course (one student dropped after a week in the course)

All responses to initial Voice Thread postings

Secondary instructional strategies utilized (Robert Marzano, Oliver \& Shaver, 4MAT, Edward deBono, Madeline Hunter)

Analysis of student self-reflection completed after the audio/visual experience

\subsection{Data Analysis}

The extensive body of data was analyzed using a qualitative process driven by a grounded theory approach (Strauss and Corbin 1998). This data was significant in addressing the research questions and secondary questions described above. Postings are presented as they were presented within the Voice Thread and self reflection completed after the audio/visual experience. No spelling or content changes were made by investigators.

$R Q 1$. How did teacher candidates incorporate secondary teaching methods into an audio/visual tool such as Voice Thread? This investigation question was addressed through an organized content analysis of the teacher candidates' creation of the Voice Thread content. This analysis included the following elements, each designed to address a specific secondary question:

$R Q$ 1.1. What did teacher candidates record in Voice Thread? This examination involved documenting the number of postings, types of audio/visual media used, and information provided within each of the Voice Thread creations by the teacher candidates as well as their responses to others' Voice Thread creations with the goal of identifying the range of topics, accuracy of information on instructional strategies, and any other information included, each of the initial Voice Thread posts and responses to initial posts were coded according to the issue or focus of each particular post (referred to as the theme of that post; e.g., instructional strategies, pedagogy, etc.) The codes subsequently produced were finally housed under larger categories to better address teacher candidates' use of audio/visual media in a classroom setting and apply comparisons with the literature regarding key issues they need to tackle as they move forward toward their goal of initial teacher certification.

$R Q$ 1.2. What comments did teacher candidates share on classmates' Voice Thread media? This examination involved documenting the types of comments and ideas shared with the creators of each Voice Thread as each student was required to view and post a comment about what they saw on audio/visual media presented. This data analysis was intentional to focus the extent to which students 
engaged in meaningful commentary based on interaction with the Voice Thread experience to the extent that the literature has recognized as promoting meaningful learning experiences.

RQ2. How did the use of Voice Thread influence the perceptions of teacher candidates who engaged in the audio/visual experience? As a supplement to the Voice Thread learning opportunity, the students were required to provide a self-reflection narrative regarding the use of audio/visual media. As participation in the Voice Thread was required, examination of what, if any, carry over from that experience affected student perceptions of audio/visual media as a means of learning.

\subsection{Key Findings}

$R Q 1 . H o w$ did teacher candidates incorporate secondary teaching methods into an audio/visual tool such as Voice Thread?

The main thrust of the Voice Thread requirement was to provide the class with information, examples, and evaluation of one assigned instructional strategy. As such, each group did provide some type of Voice Thread audio/visual presentation, but they varied significantly in material, resources, accuracy, and audio/visual information on instructional strategies. It is significant to note that not one group actually applied their assigned instructional strategy into the teaching of that specific instructional strategy. In other words, if the group was assigned the instructional strategy of de Bono's thinking caps, they did not actually apply de Bono's instructional strategy to inform the class of the instructional strategy. The audio/visual presentations were not application based, but more of knowledge transmission. Specific discussion of what was recorded in the Voice Thread presentation is provided.

$R Q$ 1.1. What did teacher candidates record in Voice Thread?

While the student creations of VT were interesting to view, it is significant to identify what they were addressing with each group's VT presentation of an instructional strategy useful when teaching secondary students. An important factor to the purpose of Voice Thread media is the opportunity to include audio/visual resources. While the students did provide audio resources to the Voice Thread, not one of the groups utilized video materials from outside sources or group sources. In other words, for this visual media experience, not one group utilized the option to include video examples. With the popularity of YouTube, EduTube, and other free and easy-to-obtain appropriate video sources, it seems important to note that none were used at all in this audio/visual learning experience. Throughout the duration of the course, prior to and after this assignment, the instructor utilized video examples for learning opportunities. Important to note, the students did have an online tutorial presentation on VT with at least three examples provided. Each of the examples provided did include videos. As such, the students did have first-hand knowledge with the use of videos for learning.

Each group did include at least two photographs as visuals in their VT. These photos were free and open to the public to use. No group utilized personal photos related to the instructional strategy that they took especially for the VT or had used prior to, but still had relevance for the presentation. These were photographs that anyone searching the internet could have located and used. Interesting to note, not one group provided any citations for these photos. The photographs were general in theme meaning that they could have been used for any of the groups' presentations. The photographs were not specific to any one instructional strategy or presentation.

What was important in the VT presentations was the inclusion of text. There was an abundance of text utilized by each group. Each group used standard word documents with detailed descriptions of the instructional strategy. Actually, they included too much narrative text in each "section" of VT. They, meaning each group, included more text per section of VT than would be appropriate for a PowerPoint presentation. It was important to note only one group provided the type of citation used for the textual material. While VT can be enlarged to fit the entire computer screen, each group included so much narrative text for at least half of the presentation, that some of it could not be read without the viewer modifying the size of the font. VT is not designed for such dependence on text. It is an audio/visual tool. Every group but one, did provide at least one group member talking/commenting on that particular text, but it was merely reading the text to the viewer not providing any new information or explanation of the information.

Another aspect of textual information the groups provided was graphic organizers. Within the context of the course, each student had to provide at least two graphic organizers to support their reading comprehension. As such, the students may have believed the graphic organizers were necessary to the 
VT as well. Every group included some type of graphic organizer within their VT presentation. These graphic organizers were not a requirement of the assignment. Incidentally, not one group provided audio explanation of the graphic organizer. It was just included as another slide or "section" of the VT. It seems they were included as an after- thought, material filler and/or as a continuation of the course requirements.

While each group did provide accurate, important information for each of the assigned instructional strategies, the spirit of the assignment was missed. Students did not seem to grasp the purpose of Voice Thread as an audio/visual tool for communicating information, ideas, and opinions. While each student did indicate he/she would use VT in the future with his/her own classroom, they did not seem to truly understand its purpose in learning with audio/visual media.

$R Q$ 1.2 What comments did teacher candidates share on classmates' Voice Thread media?

An important factor to learning in an online course is for students to interact with each other and the work that is contributed. As such, the Voice Thread audio/visual media encourages interaction so this learning experience required audio interaction. While VT, allows for audio communications, textual communication can be used. Interesting to note, this learning opportunity required that the students comment at least twice on other students' VT presentation. It was not specifically noted to use audio communication. Consequently, only three students actually used the audio capability to provide his/her comments. As VT is an audio/visual tool, it seemed to the investigators that students would utilize the audio communication option without making it a requirement. This assumption will be addressed in the discussion section of the paper.

Each communication, whether audible or textual, was analyzed and placed into relevant categories. Two themes of communication were determined: personal learning and pedagogical knowledge. These themes were identified after reading each of the communications contributed by participating students. For this investigation, personal knowledge relates to prior experiences and information that a student possesses and brings to the learning experiences, such as their own learning experiences with new information or specific teachers they remembered from their school days. This knowledge relates to thinking of how new information or knowledge benefits oneself as an individual. Pedagogical knowledge is that which relates to the art of teaching; more specifically, instructional theory and ideas. Pedagogical knowledge would be that information which they learned in educator preparation courses such as how to write a lesson plan or various classroom management strategies.

While personal learning plays a role in how one develops as a teacher, it is still egocentric in nature. Almost half of the comments made regarding the VT of fellow classmates were personal in nature. According to student Julie regarding the ideas of Dr. Edward de Bono and his thinking hats originally created in the 1985s, (as presented by her classmates (no spelling or writing changes were made to student words):

I like this visual because it makes the hats easier to remember. Also, this visual

and the words associated with each hat help me tie in the color to the meaning.

For example, the green hat makes me think of Spring which is the time for new

things, black makes me think of dark and scary which would be bad, yellow

makes me think of a bright and sunny day which is good, and so on. For me, this

is a great tool to increase my retention.

Tanya

I really like the concept of the different color "thinking hats". This is an interesting concept.

Brooke

I do like the outline formats that are in Marzano's strategies. There is more than one to choose from so certain kids can choose what they feel fits them the best. Outlines are so important in classes I feel because you can tell how much a student is learning and comprehending.

The following students portrayed a sense of pedagogical knowledge with the comments they shared on the VT of fellow classmates.

Wendell

I like this type of lesson plan when you want to cover something in depth. By using each hat in order, you ensure that nothing is left out of the lesson. I think that this type of lesson would be especially strong in classes like environmental science.

$\mathrm{Zac}$ 
Marzano's focus on group learning and motivation makes a lot of sense. The students will be more apt to participate and put forth a good effort if the assignment has real world applications.

Zac

The ability to explain the importance of a lesson, teach it, and then review that lesson is so crucial in the students being able to keep that knowledge long term.

RQ2. How did the use of Voice Thread influence the perceptions of teacher candidates who engaged in the audio/visual experience?

Reflection is an important aspect of learning, preparing, and practicing to be a professional educator. As such, each student completed a self-reflection narrative after the VT learning experience was completed and before any grades were provided. As these were teacher candidates, several reflection question/statements were provided, but not required or limited to student attention. The following were provided by the instructor:

How was creating the VT?

How was using it as a learning tool?

How would you use it in the future?

Positives about VT?

Negatives about VT?

Any other comments you wish to share.

The student comments from their self-reflection were read, categorized, and placed in a relevant group; Communication, Collaboration, and Creation/Creativity. These three groups were identified based upon the actual comments students made in their reflections about the VT experience. For this investigation, collaboration is the act of students working together to produce a meaningful product that demonstrates a learning experience. Creation/creativity relates to students having the opportunity to produce a learning experience that affords them freedom to make individual and group choices about a product, resources, and materials used in an effort to make something original. Communication is the interaction among/between students as a means to discuss and share learning ideas and products.

Collaboration was a theme prevalent in the student reflections.

Ashley

Voice Thread allows an opportunity for all students to participate in an exciting assignment.

Jessica

...I plan to use voice thread occasionally in my classroom by posting daily problems or asking the students to post questions they have on their homework for other students to possibly help them out with.

Brooke

I think kids can feel more interactive with other students if they used it.

Punam

I found that you can produce something great and learn from each other's research rather than trying to do everything on your own. Also, going through other group's VT and learning from their work without much effort was rewarding.

I would use VT for group learning and for out of class learning where I can provide feedback along the way. For group learning I would split my class in groups and assign them same or different topics to research.

Creation/Creativity allows students to work from their imagination to produce original work that does not have a set "right or work" answer, but rather an openness to student thoughts and ideas. A pattern of creation/creativity was determined from review of the student reflections.

Jessica

I believe that voice thread can be used to allow the students more creativity in some of the lesson and this might keep them more interested in particular lessons.

Destiny

The VT is a fun interactive tool that will have the students reading, discussing, and thinking. The students will be more involved in their studies than just reading book and notes. 
Brittany

If you incorporate something such as Voice Thread where technology is involved and it will allow them to be creative and have fun...

Punam

One big advantage I see is that students of all learner types can benefit from this.

It also takes you out of mundane book and notebook learning process.

Julieta

Some of the positives of working with VT were the ease of use, the versatility, and the attractive end result.

Communication is a vital element to anyone learning. For the Voice Thread experience, here is what the students had to say in their reflection regarding communication.

Ashleigh

This virtual learning tool, allows teachers and students to continue vocal communication outside of the classroom.

I did notice that Apple provides and application for this that can be used on any Apple device. This is great because many students may not have computer access, but most have smart phones and tablets.

Wendell

All complaints aside, voice thread would be a powerful tool for social history by giving them more time to think and see what others say outside of the time constraints in class.

I think that I will likely eventually use the voicethread for prep work for class debates or discussions. I could post a lecture online then the students could post comments to give everyone help in thinking about the topic before class.

Destiny

The VT gives the opportunity to share ideas and also here others ideas over different content. The tools they give you to allow discussion and participation on the VT only make using it more enjoyable.

Brooke

I would use it in the future actually. It was simple and you can respond either by talking or typing so that was nice.

The options to speak or type were a good thing.

Punam

It's a great tool to share any idea, thoughts, project and results of a research with others. It also allows various feedback mechanisms like audio, video and notes which makes it very interactive.

\section{Discussion and Implications for Teacher Education}

It is necessary to address the overarching question of how teacher candidates' perceptions of audio/visual media affects teaching and learning in a secondary classroom. In general, the literature review confirms the use of audio/visual media such as Voice Thread in such classrooms. What is important at this juncture is to determine how best to prepare these teacher candidates to utilize such media in their classrooms as a means to promote meaningful learning.

The teacher candidates in this investigation were willing and able to apply the necessary technology of the Voice Thread. Their willingness was apparent as all sixteen of the students enrolled in the semester course did actually post the required VT with their group. The VT tool was utilized and did meet the assignment requirements, but at a lower-level of thinking. In other words, the teacher candidates spent a great deal of time posting basic, textual information of what they had read in textbooks or viewed online via the internet. Summaries do provide an opportunity to check learner comprehension as well as submit definitions and explanations of instructional strategies, however, very few, if any, of the teacher candidates included an evaluation of the instructional strategy along with the summary submitted. No one of the groups submitted a relevant video that described or summarized or 
applied their assigned instructional strategy. In other words, it appears the Voice Thread was used as a place to regurgitate information, not to evaluate it, apply it, or debate it.

This investigation demonstrates that teacher candidates are able to read and view the required course materials and resources, to sort that information, to organize it in some manner, and to put their thoughts into understandable presentations. Unfortunately, these presentations were to take the form of audio/visual media. While some audio and some visuals did exist, they were at a low-level of skill, especially the visual aspects. Each Voice Thread presentation was done so in a manner that related to the assigned instructional strategy, the materials and resources. However, no personal examples were provided and no appropriate videos were presented that could have taken the place of personal experiences. Granted, much of the VT was done with visual brevity and textual abundance, but this nevertheless provided some confirmation that students did at least comprehend the instructional strategy in at least a surface level. A possible limitation to what the students posted could be that more specific guidelines were not provided at the onset of the course. It does seem reasonable to believe that guidelines for VT presentations on any topic are necessary in terms of what and how students post as audio/visual materials.

It seems apparent that each of the students realized the ease, variety and importance of communicating with fellow classmates whether as a group member or classmate reviewing a presentation. Even though not every student provided the required comment on their classmates' presentations, almost every student did reflect on the importance and ease of such communication via VT.

One cannot collaborate without some type of communication. As almost every teacher candidate did mention the ability to communicate with fellow students using VT, collaboration must be addressed. Teacher candidates should work together as a means of preparing for their own classrooms. No teacher can or should work in isolation. As collaboration is a part of learning, it stands to reason that collaboration can take place online as well as face to face. The VT provides that online collaboration component that can be used in a secondary classroom. As one of the patterns established from the comments on the self-reflection, the teacher candidates seem to understand the role collaboration should play in learning. As the digital natives probably already know, collaborating online can be just as easy as collaborating off line. Teachers just need to know that piece of information as well as know various technical tools to make the collaboration successful. In other words, these teacher candidates are at the beginning stages of Voice Thread mastery. They expect their future students to achieve mastery of VT, but did not have them same expectation for themselves. While the teacher candidates did communicate and collaborate during the VT experience, their work and comments were literal and lacked depth of thought. Thus, their VT product was not considered to be original or creative in presentation. Their audio/visual products were merely recreations of internet resources.

Schools of educator preparation need to include these types of learning experiences into their methodology classes. Teacher candidates need experiences in communicating and collaborating as they seek to master pedagogy. The more first-hand experience these future educators have with audio/visual media, the more likely they are to utilize it with their own students, but they must be exposed.

A significant part of learning is how one perceives his/her identity, subject knowledge, and pedagogical knowledge. These identities are developed based upon students' as well as teacher candidates' ability to contribute and influence others. In fact, true learning requires access and opportunity to contribute to a community. As such, Voice Thread provides a location for students and teacher candidates to acquire, contemplate, and share knowledge with others or his/her community of learners. Using VT as a learning tool, affords teacher candidates and ultimately, their students, the opportunities to acquire new knowledge as well as how to address learning challenges that may develop while interacting with others. It is this interaction in such audio/visual media that empowers learners to glean knowledge from text materials, people, and university coursework to actively participate in a community that welcomes a variety of thoughts and ideas.

As teacher candidates conclude their teacher preparation program, it is the rare student who did not have meaningful access to the use of a variety of technical tools to promote their understanding of teaching and learning. Using VT as a teaching and learning tool supports the notion that students and teacher candidates of the $21^{\text {st }}$ century desire and require learning opportunities that include audio/visual media. The technological tool, such as VT, allows students to share their ideas and perspectives in a public setting. Student motivation to learn is the need to participate in some type of learning community and in this investigation, the Voice Thread served as such a community. 


\section{Related References}

1. American Association of Colleges of Teacher Education (AACTE). (2008). The handbook of technological pedagogical content knowledge for educators. New York, NY: Routledge.

2. Bennett, S., Maton, K., \& Kervin, L. (2008). The digital natives debate: A critical review of the evidence. British Journal of Educational Technology, 39 (5), 775-786.

3. Brown, C., \& Czerniewicz, L. (2010). Debunking the 'digital native': Beyond digital apartheid, towards digital democracy. Centre for Educational Technology, (26), 357-369.

4. Brunvand, S., \& Byrd, S. (2011). Using voice thread to promote learning engagement and success for all students. Teaching Exceptional Children. 43 (4), 28-37.

5. Coiro, Julie, and Elizabeth Dobler (2007). Exploring the online reading comprehension strategies used by sixthgrade skilled readers to search for and locate information on the Internet. Reading Research Quarterly, (42) 214257.

6. Davis, L. (2002). Bending over backwards. New York, NY: New York University Press.

7. deBono, E. (1985). Six Thinking Hats. New York, NY: Little, Brown and Company.

8. Gee, James (2003). What video games have to teach us about learning and literacy. New York: Palgrave.

9. Howe, N., \& Strauss, W. (2000). Millennials Rising: The next great generation. Vintage Books, New York: NY.

10.International Society for Technology in Education (ISTE). (2002). National Education Technology Standards for teachers. Retrieved September 23, 2013 from http://www/iste/org

11.Irving, Karen (2006). The impact of technology on the 21st century classroom. In Teaching Science. In the 21st century", J. Rhoton and P. Shane (Ed.). Arlington, VA: NSTA.

12.Johnson, L., Levine, A., Smith, R., \& Smythe, T. (2009). The 2009 Horizon report: K-12 Edition. Austin, TX: The New Media Consortium.

13.Leu, Donald.J.Jr., Kinzer, Charles.K., Coiro, Julie., Cammack, Dana(2004). "Toward a theory of new literacies emerging from the Internet and other information and communication technologies". In R.B. Ruddell \& N. Unrau (Eds.), Theoretical Models and Processes of Reading, (Fifth Edition ). Retrieved March 2, 2012 from www.readingonline.org/newliteratices.lit.index, asp?HREF =newliteracies/leu.

14.Leu, Donald.J. Jr., Zawlinski, Lisa., Casterk, Jill., Banjeree, Manju., Housand, Brian., Liu, Yingjie. et al. (2007). What is new about the new literacies of online reading comprehension? A. Berger, L. Rush, \& J. Eakle (Eds.) Secondary school reading and writing: What research reveals for classroom practices. Chicago, IL: NCTE/NCRL

15.McKenzie, J., (2007). Digital nativism, digital delusions, and digital deprivation. From Now On: The Educational Technology Journal, $17 \quad$ (2). Retrieved, September 28, 2013, from http://fno.org/nov07/nativism.html.

16.Mishra, P., \& Koehler, M. (2006). Technological pedagogical content knowledge: A Framework for teacher knowledge. Teachers College Record, 108 (6), 1017-1054.

17.National Council for Accreditation of Teacher Education (NCATE). (2008). Professional standards for the accreditation of teacher preparation institutions. Washington, DC: Author.

18.Oblinger, D., \& Oblinger, J. (2005). Educating the Net Generation. Educase, Boulder, CO.

19.Perillo, S. (2007). Reaching generation Y: To be or not to be relevant. Australian

Anglican Schools Network, Melbourne, 17-19.

20.Partnership for 21st Century Skills \& American Association of Colleges of Teacher Education. (2010). 21st century knowledge and skills in teacher educator preparation. Retrieved from http://www.p21.org/documents/aacte_p21_Whitepaper2010.pdf

21.Prensky, Mark (2001). Digital natives; Digital immigrants. On the Horizon 9/5. Last modified June 24, 2013. http://www.marcprensky.com/writing/default.asp

22.Redman, C. \& Trapnai, F. (2012). Experiencing new technology: Exploring pre-service teachers perceptions and reflections upon the affordances of social media. Paper presented at Joint AARE and APERA International Conference, Sydney, Australia.

23.Russell, M., Bebell, D., O'Dwyer, L., \& O'Connor, K. (2003). Teacher's belief about and use of technology: Enhancing the use of technology for new and veteran teachers (Report\#5). Boston, MA: Boston College, Technology and Assessment Study Collaborative. Retrieved September 20, 2013 from http://www.bc.edu/research/intasc/library/seitreports.shtml 
24.Shulamn, L.S. (1986). Those who understand: Knowledge growth in teaching. Educational

Researcher, 15 (2), 4-14.

25.Street, Brian (2003). What's new in new literacy studies? Current Issues in Comparative Education, (5/2): 1-4.

26.U.S. Department of Education. (2010). Transforming American education: Learning powered

by technology. Washington D.C: Office of Educational Technology, U.S.

Department of Education. Retrieved September 21, 2013 from http://www.edgov/

technology/netp-2010

27.Yin, Robert.K. (2003). Case study research: Design and methods. Thousand Oaks, CA: Sage. 